\title{
Margaret McCartney: There's no magic GP production line
}

\author{
Margaret McCartney general practitioner
}

Glasgow

The new plan to save the NHS in England is for "every hospital A\&E department" to have GP triage. I'm a fan of GPs-after all, I am one. General practice is terrific, even when we're not all wearing Wonder Woman bustiers. But this is another example of calamitous policy making.

Firstly, GPs are not rabbits, which breed regularly, easily, and joyously. It takes a long time to train GPs, and they then have an awful tendency to look at the NHS and think: maybe only part time, maybe only after I've been to Australia.

But lo! We're getting 5000 extra doctors in general practice, delivered jointly with Health Education England, which must be a very special GP breeding ground, as it will have to hatch GPs for every emergency department too, along with-Simon Stevens said it, so it must be true- "comprehensive front door streaming with GPs by next Christmas." ${ }^{2}$

Continuity of care is a powerful antidote to harmful uncertainty and overtreatment of people whose presentation is often chaotic

I asked NHS England for the evidence. How do we know that putting GPs into every emergency department will make every hospital a top performing hospital, as Stevens says Luton and Dunstable is? There's "nothing published on that yet," I was told.

In support, they did send me a report by the Primary Care Foundation. They may not have read the report, because it said, "A GP working in the [emergency department] may result in less referrals for admission and less tests being undertaken. Cost benefits may exist but the evidence is weak."

It added, "There is a paucity of evidence on which to base policy and local system design. There may be benefits of joint working between primary and emergency care but at present this cannot be said to be evidence based."

But don't just listen to NHS England contradicting itself.

Cochrane has looked at the research on this issue and concluded, "The evidence from the three included studies is weak, as results are disparate and neither safety nor patient outcomes have been examined." ${ }^{4}$ And a study of locating primary care centres inside emergency departments found that it paradoxically increased demand without improving throughput. ${ }^{5}$

Then there's the hazardous public confusion about who works where, and where to go for what. We have enough people still avoiding admission at the weekend and waiting until Monday, ${ }^{6}$ without adding to the confusion.

If you take GPs out of general practice they're no longer in it. If you put GPs in emergency departments they may offer some services to some people; but they won't be able to offer continuity of care, the special magic ingredient of general practice that acts as a powerful antidote to harmful uncertainty and the over-investigation and overtreatment of people whose presentation is often chaotic. This magic ingredient may be invisible, but it definitely exists, unlike the magic GP reproduction machine.

We need evidence based policy making: stop doing things that don't work, and don't start things that we don't know work outside experimental conditions.

\section{Competing interests: See www.bmj.com/about-bmj/freelance-} contributors/margaret-mccartney.

Provenance and peer review: Commissioned; not externally peer reviewed.

Follow Margaret on Twitter, @mgtmccartney

Department of Health. The government's mandate for NHS England for 2017-18. Mar 2017. https://www.gov.uk/government/uploads/system/uploads/attachment_data/file/ 601188/NHS_Mandate_2017-18_A.pdf.

2 lacobucci G. All emergency departments must have GP led triage by October. $B M J$ 2017;357:j1270. doi:10.1136/bmj.j1270 pmid:28283472.

3 Carson D, Clay H, Stern R. Primary care and emergency departments: report from the Primary Care Foundation. Mar 2010. www.primarycarefoundation.co.uk/images/ PrimaryCareFoundation/Downloading_Reports/Reports_and_Articles/Primary_Care_and Emergency_Departments/Primary_Care_and_Emergency_Departments_RELEASE.pdf.

4 Khangura JK, Flodgren G, Perera R, Rowe BH, Shepperd S. Primary care professionals providing non-urgent care in hospital emergency departments. Cochrane Database Syst Rev 2012;357:CD002097.pmid:23152213.

5 Ramlakhan S, Mason S, O'Keeffe C, Ramtahal A, Ablard S. Primary care services located with EDs: a review of effectiveness. Emerg Med J 2016;357:495-503. doi:10.1136/ emermed-2015-204900 pmid:27068868.

6 Gan H-W, Kanaris K. Results of the Hunt effect surveys in response to "Increased mortality associated with weekend admission; a case for expanded seven day services?" BMJ 2015. http://www.bmj.com/content/351/bmj.h4596/rr-52. 
Published by the BMJ Publishing Group Limited. For permission to use (where not already

permissions granted under a licence) please go to http://group.bmj.com/group/rights-licensing/ 